\title{
Construct Validity in Research Development Instruments: The Analysis of Self-Discipline Factors
}

\author{
Rr. Agung Kesna Mahatmaharti ${ }^{1}$, Wayan Ardhana ${ }^{2}$, Triyono ${ }^{3}$, \\ Fattah Hanurawan ${ }^{4}$ \\ ${ }^{I}$ STKIP PGRI Jombang, East Java, Indonesia \\ ${ }^{2,3,4}$ Universitas Negeri Malang, East Java, Indonesia
}

\begin{abstract}
Self-discipline is the infinite capital in building a quality person to achieve success through the ability of individuals to delay satisfaction and self-control and self-regulate in an effort to develop one' potential. The dimensions of self-discipline cover the following things: (1) the ability to delay satisfaction; (2) the ability to control oneself; and (3) the ability to self-regulate. This research is a research development that aims to produce self-discipline measure instrument of learners who named self-discipline scale. Development of self-discipline scale is done in two stages that are: (a) prototyping phase, and (b) assessment phase. The findings of this study indicate the indicators that represent dimensions are: (1) the ability in delaying satisfaction is not delaying school work. Indicators that represent dimensions; (2) the ability to control oneself are able to impose themselves (positive things), able to control the impulse, and able to strengthen themselves (positive). While the indicators that represent dimensions are (3) the ability to self-manage is capable of making decisions, able to keep promises themselves, able to monitor themselves, and able to determine their own goals.
\end{abstract}

Keywords: Self Discipline, Postpone Satisfaction, Self-Control, Self-Regulation

\section{INTRODUCTION}

Bearing a qualified person requires such a capital, one of which is self-discipline. In the world of education, self-discipline is one of the main aspects for learners in an effort to develop their potential. Discipline should be viewed as a positive and constructive force that refers to an awareness that begins with obedience to the prevailing rules and sets the tack to bring the desired and important thing to it (Taylor, 1987; Kohlberg, 1991, Parker, 2006; Kohn, 2008). Self-discipline is very influential on the achievement of academic achievement through the rejection of the delay and is a self-control that forms the spiritual, emotional, and outward discipline (Duckwonth \& Seligman, 2005; Sasson, 2003; Knapczyk, 2004). Self-discipline is created by acknowledgment, willpower, hard work, perseverance, and tenacity and possesses realistic traits, can design goals and be motivated and have more detailed goals (Pavlina, 2006; Folkman, 2009; Gong et.al, 2009). So that self-discipline can be measured through the dimensions of self-ability in delaying satisfaction, self-control, and self-regulating ability. The dimension of self-discipline through the ability to delay gratification, self-control and self-regulation suggests a part that can be used to measure self-discipline. Delaying satisfaction is one's ability to delay temporary satisfaction that leads to goal attainment and abstinence shown to predict desired outcomes in the future through self-control and self-regulation processes (Mitchel et al., 1989; Metcalfe and Mitchel, 1999; Cuskelly et al., 2001). In order to function effectively, the individual must voluntarily postpone temporary satisfaction and keep in the direction of goal behavior for later results (Mitchel et al., 1989).

The ability to have self-control in the discipline shows regularity in internal compliance with an inward impulse (Durkheim, 1990; Beiley, 2004). Self-restraint to resist impulses from within is a momentary stimulus and contradictory to social norms, controlling harmful and emotional actions, and decision-making through behavioral, cognitive and judicial control (Clark, 1990; Berk, 1993; Gilliom, 2002). Self-regulating ability is needed in improving self-discipline (Duckworth et al., 2011). Self-organizing ability is shown in the process of generating thought and active involvement in goal setting, self-monitoring, self-governance and self-oriented self-assessment or positive motivation and self-consistency through dynamic interaction. (Schunk \& Zimmerman, 1997; Zimmerman, 2000; Senko \& Harackiewicz, 2005; Woolfolk, 2010).The development of self-discipline instrument is tested for reliability and validity to produce valid, practical, and effective selfdiscipline measurement scales. Testing the validity is done through: (1) content validity; (2) predictive validity; (3) construct validity. Construct validity includes the basic question of whether the resulting score has a useful purpose and positive impact when practiced in real life (Creswell, 2009). The construct validity test is also a test of the validity of the theory that determines the alleged meaning of an action for and measures validation and anticipates the homogeneity of unidimensional and unidimensional traits as objects of theoretical studies 
(Edwards 2001; McGrath 2005; Smith et al., 2003; Smith \& Combs , 2008). The construct validity test describes the methods and rules of conclusions in which a person develops evidence of validity measurement such as hypothetical construction (Cronbach \& Meehl, 1955).

The development of self-discipline must be the responsibility of educators, especially in schools needs to use a touching approach to developing self-discipline of learners, correcting behavioral problems, preventing behavioral problems, and handling learners with behavioral problems seriously. So the self-discipline scale instrument needs to be developed to measure the level of discipline that comes from within the learner.

\section{RESEARCH METHODS AND DEVELOPMENT INSTRUMENTS}

This research is a developmental research which develops an instrument to measure self-discipline called Self-Discipline Scale. The main purpose of this study is to produce a valid, practical, and effective selfdiscipline measurement scale. The population in this research is 286 students of eight graders at State Junior High School in Ploso and Plandaan sub-district of Jombang Regency which at this stage there is still one year to develop self potential with a change in self-discipline.

Researchers refer to the theory of self-discipline dimensions expressed by Zimmerman and Schunk (2001), Gilliom et al. (2002), Mitchel et al. (1989). The dimensions of self-discipline cover the following points: (1) self-regulating ability; (2) the ability to control oneself; (3) ability to delay satisfaction. Table 1 shows the dimensions and indicators of self-discipline in instrument development.

Table. 1

Dimension and Indicator of Self Discipline

\begin{tabular}{|c|c|c|c|}
\hline Variable & Dimension & Indicator & $\begin{array}{l}\text { Problem } \\
\text { Number }\end{array}$ \\
\hline \multirow{16}{*}{$\begin{array}{l}\text { Self- } \\
\text { discipline }\end{array}$} & \multirow{2}{*}{$\begin{array}{l}\text { The ability of self } \\
\text { regulation }\end{array}$} & Able to determine his/her own goal & $1,2,3,4$ \\
\hline & & Able to control his/herself & $5,6,7$ \\
\hline & \multirow{5}{*}{$\begin{array}{l}\text { (Zimmerman and Schunk, } \\
\text { 2001) }\end{array}$} & Able to instruct his/herself & $8,9,10,11$ \\
\hline & & Able to evaluate his his/herself & $12,13,14,15$ \\
\hline & & Able to force his/herself & $16,17,18,19$ \\
\hline & & Able to strengthen his/herself (positive) & $20,21,22,23$ \\
\hline & & Able to fulfill his/her own promise & $24,25,26,27$ \\
\hline & \multirow[t]{2}{*}{ The ability of self control } & Able to control emotion & $28,29,30,31$ \\
\hline & & Able to control enforcement & $32,33,34,35$ \\
\hline & \multirow[t]{3}{*}{ (Gilliom, MS et al,2002) } & Able to make decision & $36,37,38,39$ \\
\hline & & Able to taking action & $40,41,42,43$ \\
\hline & & Able to control toward stimulation & $44,45,46,47$ \\
\hline & $\begin{array}{l}\text { The ability to delay of } \\
\text { gratification }\end{array}$ & $\begin{array}{l}\text { Be bold to quit temporary enjoyment and } \\
\text { satisfaction }\end{array}$ & $48,49,50,51$ \\
\hline & \multirow{3}{*}{ (Mitchel W. et al, 1989) } & Be bold to say no toward instant achievement & 52,53 \\
\hline & & $\begin{array}{l}\text { Learning in gaining something through } \\
\text { process }\end{array}$ & $54,55,56,57$ \\
\hline & & Not delaying work & $58,59,60,61$ \\
\hline
\end{tabular}

The development of self-discipline instrument is the main activity in this research. The development of this selfdiscipline instrument is carried out in two phases: (a) prototyping (prototyping phase), and (b) assessment (phase assessment). The following are consecutive activities described at each stage of development.

\subsection{Prototyping Phase}

The instrument of Self Discipline as an instrument to measure the discipline of learners. The instrument of selfdiscipline is designed in the form of statements. The statements are based on indicators of self-discipline. While self-discipline indicators developed based on the dimensions of self-discipline.

\subsection{Assessment Phase}

Activities undertaken at this stage are field trial activities aimed at finding out whether the self-developed selfdiscipline instrument (prototype 1) meets the criteria of honesty of respondents in answering, reliably and constructively validity through exploratory factor analysis. The flow of self-discipline instrument development activity is shown in Figure 1. 


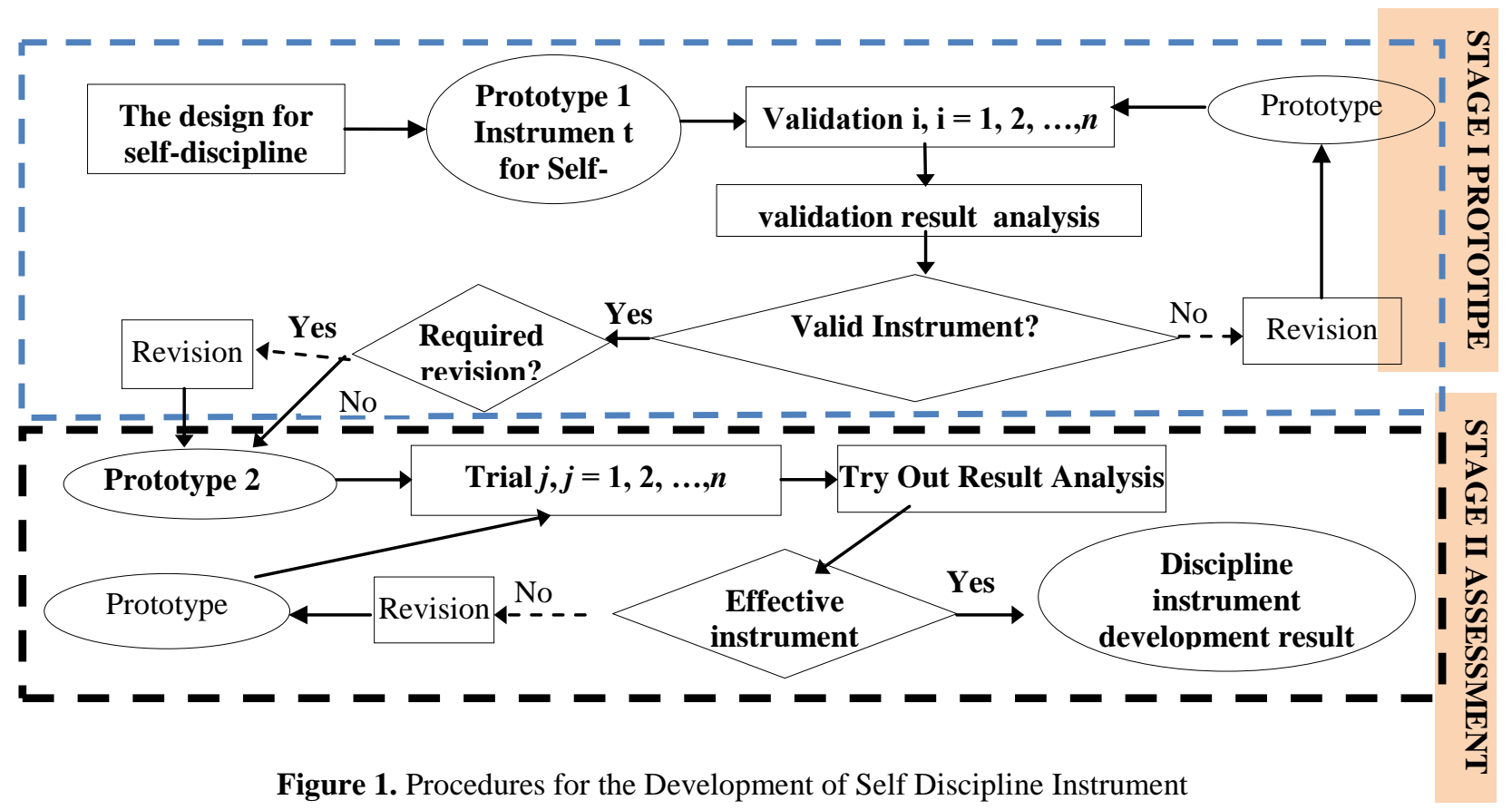

Instrument of self-discipline is in the form of questionnaires. This questionnaire uses statements to be answered by respondents by choosing an alternative answer provided. The measurement scale of the questionnaire uses a measurement method developed by Likert (Likert Scale). The Likert Scale used is disagree, quite disagree, hesitating, agree, strongly agree, then being rated 1, 2, 3, 4, 5 for each answer in sequence. Researchers develop the statements that are in the questionnaire based on Dimensions and self-discipline indicators.

\subsection{Data Analysis Technique \\ 2.3.1 Outlier Test}

Researchers have no way of ensuring that respondents do not lie or answer carelessly. Therefore, the researcher conducts an outlier test to eliminate abnormal data that has a standard deviation value of less than or more than 2.50 .

2.3.2 Cronbach's alpha Reliability Test

Cronbach's alpha reliability test was used to measure the reliability of the indicators used in the research questionnaire. So that researchers will get indicators and statements that can measure self-discipline. The researcher assigned the Corrected Item-Total Correlation value of 0.350 as the escaped value to obtain a more accurate test value.

\subsection{Exploratory Factor Analysis}

Exploratory factor analysis is an analytical technique of several factors that will be formed in the form of latent variables that cannot be determined before the analysis is done. In principle, exploratory factor analysis prior to the formation of factors is random which can then be interpreted in accordance with the factors or components or constructs that are formed, thus the exploratory factor analysis is a technique to help build a new definition that can be used to explain a large number of variables interconnected.

Santoso (2015) stated that this test is done by Barlett test of sphericity and measurement of MSA (Measure of sampling Adequacy) which in the early stages of this analysis is filtered to a number of variables to obtain variable variables that are eligible for further analysis which then through the process Factoring. The variables that have passed and then grouped in one factor has a high correlation, while the correlation with the variables on other factors is relatively low.

Each group of variables represents a basic construct called a factor. To improve factor interpretation power, transformation must be performed on the loading matrix. Transformation is done by rotating the matrix with varimax method. Testing factor analysis is done through several stages that aim to identify a number of factors that can be used to explain a large number of interrelated variables. The study specifies if a statement that has a value $<0.500$, then the item statement is annulled. 


\section{RESULT AND DISCUSSION}

The researchers gave a self-assessment instrument portfolio to 286 of eight grade students of Junior High School in Ploso sub-district and Plandaan sub-district of Jombang district in February 2017. The results of the students' answers were analyzed by outlier test, Cronbach's alpha reliability and factor analysis. Here is the discussion of the results of each test.

\subsection{Outlier Test}

Researchers have no way of ensuring that respondents do not lie or answer carelessly. Therefore, the researchers tested outliers to eliminate abnormal data. So from 286 people there are 36 pieces of data from the respondents who did not pass the next analysis. Indicator statements formulated by the researchers are a number of 16 indicators interpreted in the 61 items of the questionnaire statement.

\subsection{Cronbach's Alpha Reliability Test}

Researchers tested the reliability of Cronbach's alpha to measure the reliability of the indicators used. The result of Cronbach's alpha reliability test is presented in Table 2 by Item-Total Statistic Result that 13 items of declaration are declared because it has Corrected Item-Total Correlation value $<0.350$ which is statement item number 1, 2, 3, 14, 16, 24, 29, 30, 34, 40, 45, and 47 as in Table 2. So the researchers obtained 48 statement items that can be further analyzed.

Table. 2

Item-Total Statistics

\begin{tabular}{lccccc}
\hline & $\begin{array}{c}\text { Indale Mean } \\
\text { if Item } \\
\text { Deleted }\end{array}$ & $\begin{array}{c}\text { Indale } \\
\text { Variance if } \\
\text { Item Deleted }\end{array}$ & $\begin{array}{c}\text { Corrected } \\
\text { Item-Total } \\
\text { Correlation }\end{array}$ & $\begin{array}{c}\text { Squared } \\
\text { Multiple } \\
\text { Correlation }\end{array}$ & $\begin{array}{c}\text { Cronbach's } \\
\text { Alpha if Item } \\
\text { Deleted }\end{array}$ \\
\hline IND_1_01 & 237,5920 & 483,303 &, 316 & &, 928 \\
IND_1_02 & 238,5840 & 484,164 &, 266 & &, 929 \\
IND_1_03 & 238,2840 & 481,240 &, 347 &, 928 \\
IND_4_14 & 237,7640 & 485,330 &, 243 &, 929 \\
IND_5_16 & 238,1120 & 480,694 &, 261 &, 929 \\
IND_7_24 & 238,4480 & 480,401 &, 302 &, 929 \\
IND_8_29 & 237,7400 & 485,470 &, 205 &, 929 \\
IND_8_30 & 237,8440 & 478,325 &, 275 & &, 929 \\
IND_9_34 & 237,7720 & 477,823 &, 292 & &, 929 \\
IND_11_40 & 238,6480 & 481,257 &, 294 & &, 929 \\
IND_12_45 & 237,8360 & 476,250 &, 344 & &, 929 \\
IND_12_47 & 238,6720 & 481,418 &, 280 & & \\
\hline
\end{tabular}

\subsection{Factor Analysis Testing}

Testing factor analysis is done through several stages that aim to identify a number of factors that can be used to explain a large number of interrelated variables. In this research, some items of questionnaire statement which do not fulfill the criteria that have value $<0,500$.

Table. 3

Failed Indicator in Factor Analysis

\begin{tabular}{ll|ll|ll}
\hline \multicolumn{2}{c|}{ Pengujian 1 } & \multicolumn{2}{c}{ Pengujian 2 } & \multicolumn{2}{c}{ Pengujian 3 } \\
\hline IND_16_61 & .456 & IND_7_26 & .477 & IND_4_13 & .367 \\
IND_13_49 & .447 & IND_13_51 & .443 & & \\
IND_5_19 & .407 & IND_8_28 & .424 & \\
IND_15_54 & .363 & IND_5_18 & .365 & \\
IND_15_55 & .477 & IND_6_23 & .370 & \\
IND_7_25 & .402 & IND_7_27 & .492 & & \\
IND_11_43 & .394 & & & &
\end{tabular}




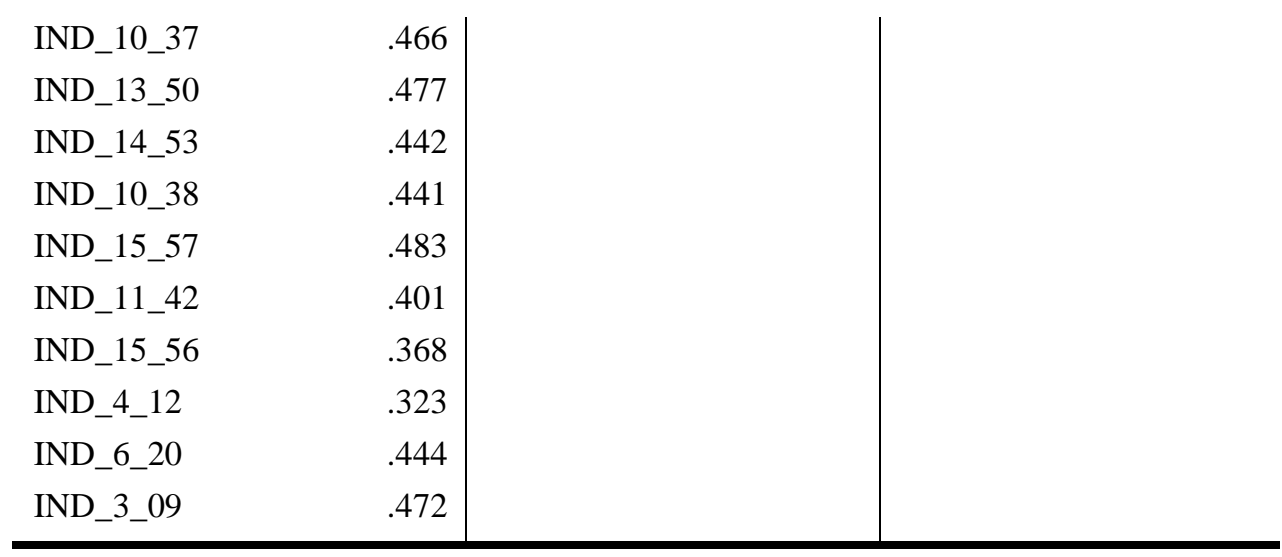

The result of factor analysis test indicates that statement items arranged based on early indicators are randomized. There are 17 items of declaration that fall in Table 3 because it has value $<0,500$. The second factor analysis test contained 6 items of declared statements and there was only 1 statement item that fell in the third test. In addition, components that meet the criteria of value have been collected into 8 components. So the remaining 24 items of statements are then performed back factor analysis as well as re-grouping statement items into new indicators formed in accordance with the component.

Table. 4

KMO and Bartlett's Test

\begin{tabular}{llr}
\hline Kaiser-Meyer-Olkin Measure of Sampling Adequacy. &, 830 \\
\hline Bartlett's Test of & Approx. Chi-Square & 1384,586 \\
Sphericity & df & 276 \\
& Sig. &, 000 \\
\hline
\end{tabular}

Results of KMO and Bartlett's test obtained by 0.83 with significance 0.00 ; The number is already eligible for further analysis because the number has exceeded 0.5 and the significance value is far below 0.05 ; So the model used can be analyzed using factor analysis.

Table. 5

Rotated Component Matrix ${ }^{a}$

\begin{tabular}{lcccccccc}
\hline & \multicolumn{7}{c}{ Component } \\
& 1 & 2 & 3 & 4 & 5 & 6 & 7 & 8 \\
\hline IND_16_58 &, 687 &, 158 &, 125 &, 161 &,- 036 &, 087 &, 190 &,- 118 \\
IND_16_60 &, 653 &, 109 &,- 067 &, 177 &, 166 &,- 118 &, 222 &, 119 \\
IND_13_48 &, 650 &, 075 &, 050 &, 097 &, 180 &, 057 &,- 110 &, 088 \\
IND_16_59 &, 639 &, 039 &, 194 &, 019 &, 034 &, 064 &,- 021 &, 369 \\
IND_11_41 &, 616 &, 134 &, 067 &, 004 &,- 010 &, 126 &, 005 &,- 026 \\
IND_3_11 &, 222 &, 729 &, 004 &,- 050 &, 095 &, 192 &, 037 &, 080 \\
IND_2_07 &, 047 &, 635 &, 030 &, 292 &, 042 &, 053 &, 119 &, 126 \\
IND_3_10 &, 290 &, 628 &, 128 &,- 085 &, 178 &, 315 &,- 096 &, 054 \\
IND_9_35 &, 234 &,- 052 &, 819 &, 037 &, 130 &, 010 &, 063 &, 014 \\
IND_8_31 &, 029 &, 124 &, 681 &, 002 &, 128 &, 319 &, 326 &,- 040 \\
IND_9_32 &,- 005 &, 210 &, 564 &, 327 &, 141 &, 185 &,- 097 &, 118 \\
IND_9_33 &, 180 &,- 072 &, 218 &, 771 &, 133 &, 103 &,- 095 &, 050 \\
IND_6_21 &, 102 &, 141 &,- 019 &, 643 &, 089 &, 164 &, 174 &, 082 \\
IND_3_08 &, 114 &, 469 &, 040 &, 508 &,- 044 &,- 026 &, 240 &,- 062 \\
IND_10_36 &,- 039 &, 300 &, 095 &, 056 &, 782 &, 001 &, 034 &,- 029 \\
& & & & & & & &
\end{tabular}




\begin{tabular}{lrrrrrrrr} 
IND_14_52 &, 201 &,- 073 &, 047 &, 155 &, 745 &, 159 &, 156 &,- 040 \\
IND_12_46 &, 155 &, 037 &, 286 &, 024 &, 587 &,- 051 &,- 016 &, 277 \\
IND_5_17 &, 097 &, 109 &, 210 &, 186 &, 041 &, 694 &, 017 &,- 045 \\
IND_6_22 &, 072 &, 151 &, 084 &, 055 &, 017 &, 660 &, 162 &, 176 \\
IND_2_05 &, 030 &, 138 &, 157 &, 112 &, 076 &, 192 &, 717 &, 150 \\
IND_10_39 &, 411 &,- 146 &,- 103 &,- 012 &, 131 &, 313 &, 513 &,- 061 \\
IND_2_06 &, 014 &, 479 &, 200 &, 163 &, 055 &,- 227 &, 506 &, 159 \\
IND_1_04 &, 089 &, 126 &, 019 &, 025 &, 038 &, 053 &, 090 &, 857 \\
IND_4_15 &, 114 &, 159 &, 009 &, 317 &, 104 &, 458 &, 187 &, 531 \\
\hline
\end{tabular}

Extraction Method: Principal Component Analysis.

Rotation Method: Varimax with Kaiser Normalization.

a. Rotation converged in 9 iterations.

Factor analysis that has been presented in Table 5 shows that the grouping of factors formed is composed of the equation or homogeneity of the content. Component 1 correlates with IND_16_58, IND_16_60, IND_13_48, IND_16_59 and IND_11_41 with values of each indicator> 0.60, whereas component 2 correlates with values> 0.60 to 0.729 with IND_3_11, IND_2_07 and IND_3_10. Component 3 correlates with IND_9_35, IND_8_31 and IND_9_32 with values> 0.56 to 0.819 . Component 4 correlates with IND_9_33, IND_6_21 and IND_3_08 with values> 0.508 to 0.771 . Component5 correlated with IND_10_36, IND_14_52 and IND_12_46>0,580 with values> 0.587 to 0.782 , whereas component 2 correlated with the value of each indicator>0.60 with IND_3_11, IND_2_07 and IND_3_10. IND_2_05: 0,717; IND_10_39: 0,513; IND_2_06: 0,506 is most correlated with component 7 . While IND_1_04 of 0.857 is more correlated with component 8 , so also IND_4_15: 0.531 goes into component 8. Being aware of factor analysis, item items are able to describe the indicators of the self-discipline dimension. So the results are then reformulated by adjusting the sequence number and self-discipline dimension indicator shown in Table 6 through Self-discipline scale instrument.

Table. 6

Indicator on Self Discipline Dimension

\begin{tabular}{|c|c|c|c|c|c|}
\hline \multirow[b]{2}{*}{ Variable } & \multirow[b]{2}{*}{ Dimension } & \multirow[b]{2}{*}{ Indicator } & \multicolumn{2}{|c|}{ No. Item } & \multirow[b]{2}{*}{$\begin{array}{l}\text { Total } \\
\text { Item }\end{array}$} \\
\hline & & & Try Out & $\begin{array}{l}\text { After Try } \\
\text { Out }\end{array}$ & \\
\hline \multirow{8}{*}{ Self Discipline } & $\begin{array}{l}\text { Able to delay of } \\
\text { gratification } \\
\text { Mitchel W. et al (1989) }\end{array}$ & $\begin{array}{l}\text { Do not delay school } \\
\text { assignment }\end{array}$ & $\begin{array}{c}58,60,48 \\
59,41\end{array}$ & $1,2,3,4,5$ & 5 \\
\hline & \multirow{3}{*}{$\begin{array}{l}\text { Able to have self-control } \\
\text { Gilliom, MS et al. (2002) }\end{array}$} & $\begin{array}{l}\text { Able to force his/her } \\
\text { own goal (positive) }\end{array}$ & $11,7,10$ & $6,7,8$ & 3 \\
\hline & & $\begin{array}{l}\text { Able to control } \\
\text { temptation }\end{array}$ & $35,31,32$ & 9. 10. 11 & 3 \\
\hline & & $\begin{array}{l}\text { Able to strengten } \\
\text { her/himself } \\
\text { (positive) }\end{array}$ & $33,21,8$ & 12. 13.14 & 3 \\
\hline & \multirow{4}{*}{$\begin{array}{l}\text { Able to organize self } \\
\text { regulation } \\
\text { Zimmerman and Schunk } \\
\text { (2001) }\end{array}$} & $\begin{array}{l}\text { Able to make } \\
\text { decision }\end{array}$ & $36,52,46$ & $15,16,17$ & 3 \\
\hline & & $\begin{array}{l}\text { Able to fulfill } \\
\text { his/her own promise }\end{array}$ & 17,22 & 18,19 & 2 \\
\hline & & $\begin{array}{l}\text { Able to supervise } \\
\text { his/herself }\end{array}$ & $5,39,6$ & $20,21,22$ & 3 \\
\hline & & $\begin{array}{l}\text { Able to determine } \\
\text { his/her own goal }\end{array}$ & 4,15 & 23,24 & 2 \\
\hline
\end{tabular}




\section{CONCLUSION}

The dimensions of self-discipline in this research cover: (1) the ability to delay satisfaction; (2) the ability to control oneself; (3) the ability to organize themselves. The results of this study show indicators and statements that correspond to the dimensions of self-discipline. These statements are used to measure the selfdiscipline of learners. Based on outlier test results, Cronbach's alpha reliability test and exploratory factor analysis indicate that the indicator representing dimension: (1) ability in delaying satisfaction is not delaying the task of school. Indicators that represent dimensions (2) the ability to control themselves are able to impose themselves (positive things), able to control the impulse, and able to strengthen themselves (positive). While the indicators that represent dimensions (3) the ability to self-manage is capable of making decisions, able to keep promises themselves, able to monitor themselves, and able to determine his/her own goals.

\section{REFERENCES}

[1]. Berk. 1993. Infant, Childrens, and Adolescents. Massachusetts: Allyn \& Bacon.

[2]. Beiley. A.Becky. 2004. Easy to Love, Difficult to Discipline: Tujuh ketrampilan dasar untuk mengubah konflik menjadi kerja sama. Jakarta: Gramedia Pustaka Utama.

[3]. Clark, R. 1990. Self Control and Self Control Therapy. Dari Ph-Weingarten, (Online), (http://www.Ph.Weingarten,de/homepage/Faechei/psycohologie/konrad/theory.html).

[4]. Creswell. J. W. 2009. Research Design. Pendekatan Kualitatif, Kuantitif dan Mixed. Terjemah dari judul asli: Research Design. Qualitative, Quantitative and Mixed Methods Approach. Pustaka Pelajar. Yogyakarta.

[5]. Cronbach LJ, Meehl PE. 1955. Construct Validity in Psychological Tests. Psychol. Bull. 1955;52:281302

[6]. Cuskelly M, Einam M, Jobling A. 2001. Delay of Gratification in Young Adults with Down Syndrome. Down Syndrome Research and Practice. 2001;7(2);60-67.

[7]. Duckworth, Angela Lee \& Seligman, Martin E.P. 2006. Self Discipline Gives Girls and Edge: Gender in Self Discipline, Grades, and Achievement Test Scores. Journal of Educational Psychology. 2006. Vol. 98. No 1.198-208.

[8]. Duckworth., Grant., Loew., Oettingen \& Gollwitzer. 2009. Self-Regulation Strategies Improve SelfDiscipline in Adolescents: Benefits of Mental Contrasting And Implementation Intention. Educational Psychology. Vol. 31, No. 1, January 2011, 17-26

[9]. Durkheim. E. 1990. Pendidikan Moral. Terjemahan Lukas Ginting. Jakarta: Penerbil Erlangga.

[10]. Edwards JR. 2001. Multidimensional Constructs in Organizational Behavior Research: An Integrative Analytical Framework. Organ. Res. Methods. 2001: 4: 144-92.

[11]. Folkman, D. 2009. Three Important Fact About Self Discipline. Dari Enzine Article, (Online), (http:/EzineArticle.com/expert=DavidFolkman), diakses 26 Desember 2012

[12]. Gilliom, MS., Beck, DS., Schonberg, JA., Michael A \& Lukon, E.L. 2002. Anger Regulation in disadvantaged preschool boys: Strategies, antecedents and the development of self-control. Development Psychology 2002. Mar; 38 (2): 222-35

[13]. Gong, Y., Rai, D., Beck, J. and Heffernan, N. 2009. Does Self Discipline Impact Student Knowledge and Learning. Journal of Educational Data Mining 2009. 61-70.

[14]. Knapczyk, D. 2004. Teaching Self Discipline: For Self-Reliance and Academic Succes. USA. Attained Company, Inc.

[15]. Kohn, A. 2008. Why Self Discipline Is Overrated: The (Troubling) Theory and Practice of Control from Within. Dari Alfie Kohn, (Online), (http://www.alfiekohn.org/teaching/selfdiscipline.htm), diakses 26 November 2012.

[16]. Kolberg, L. 1991. The Philosophy of Moral Development. San Francisco: Helper and Row.

[17]. McGrath RE. 2005. Conceptual complexity and construct validity. J. Pers. Assess. 2005;85:112-24

[18]. Matcalfe, J \& Walter Mischel. 1999. A Hot/Cool System Analysis of Delay of Gratification: Dynamic of Willpower. Psycological Review 1999. Vol. 106, No. 1, 3-19.

[19]. Mischel. W, Shonda. Y, Rodrigues. M.L. 1989. Delay of Gratification in Children. Science New Series. Vol. 244, No. 4907, 933-938.

[20]. Parker, K. Deborah. 2006. Menumbuhkan Kemandirian dan Harga Diri Anak. Terjemahan dari Judul Asli: Developing Children Independency and Self Esteem. Jakarta: PT. Prestasi Pustakarya.

[21]. Pavlina, S. 2006. Self Discipline The Key to Succes. Dari Steve Pavlina, (Online), (http://www.stevepavlina.com/blog/2005/06/self-discipline), diakses 10 Maret 2013.

[22]. Sasson, Remez. 2003. Will Power and Self Discipline. Dari Succes Concsiouness, (Online), (http://www.SuccesConsciousness.com), diakses 17 Juli 2013.

[23]. Santoso, Singgih. 2015. Menguasai statistic mutlivariat. PT. Elex Media Komputindo, Jakarta. 
[24]. Schunk, D.H \& Zimmerman, B.J. 1997. Social Origin of Self Regulatory Competence. Educational Psychologyst. 32(4). 195-208.

[25]. Senko. C. \& Harackiewicz. J. M. 2005. Regulation of Achievement Goal: The Role of Competence Feedback. Journal of Education Psychology. Vol.97, No. 3, 320-336.

[26]. Smith GT, Fischer S, Fister SM. 2003. Incremental validity principles in test construction. Psychol. Assessment. 2003;15(4):467-77

[27]. Smith GT, Combs J. 2008. Issues of construct validity in psychological diagnoses. In: Millon T, Krueger RF, Simonsen E, editors. Contemporary Directions in Psychopathology: Toward the DSM-V and ICD11. Guilford Press; New York.

[28]. Taylor, B.W. (1987). Classroom discipline: A system for getting the school adminstrator to see classroom discipline problems your way. Dayton, OH: Souther Hills Press.

[29]. Woolfolk. A. 2010. Educational Psychology Eleventh Edition. New Jersey: Pearson Education International.

[30]. Zimmerman, B. J. 2000. Attaining Self Regulation. Dalam M. Boekaerts, P. R. Pintrinch \& M. Zeidner (Ed). Handbook of Self-Regulation. San Diego: Academic Press. 